\title{
SEASONAL EVOLUTION AND DEPTH VARIABILITY OF HEAVY METAL CONCENTRATIONS IN THE WATER OF FIRIZA-STRÎMTORI LAKE, NW OF ROMANIA
}

\author{
THOMAS DIPPONGa ${ }^{a}$ CRISTINA MIHALI ${ }^{a}$, FIRUTA GOGA $^{\text {b* }}$, \\ ELENA CICAL ${ }^{a}$
}

\begin{abstract}
The paper follows the spatial variability and seasonal evolution of the heavy metal content of the Firiza-Strîmtori Reservoir that is the main source of drinking water for Baia Mare city located in the northwestern part of Romania. Water samples were collected from 10 sampling points located along the median line of the lake at different depths (at surface, at $5 \mathrm{~m}, 10 \mathrm{~m}$, $15 \mathrm{~m}$ and $20 \mathrm{~m}$ ). The experiments were carried out in the winter, spring, summer and autumn of 2015. We determined the concentration - depth profiles, both for the heavy metals iron (Fe), manganese (Mn), zinc (Zn), copper $(\mathrm{Cu})$, cadmium $(\mathrm{Cd})$, lead $(\mathrm{Pb})$ and also for sodium $(\mathrm{Na})$, potassium $(\mathrm{K})$, calcium (Ca) and magnesium (Mg). We determined the concentrations of heavy metals by atomic absorption spectrometry. We found that concentrations of heavy metals increase with depth. Generally, the concentrations of heavy metals are within the legal limits for the water used as drinking water sources. Mathematical models with high correlation coefficients were obtained in the case of heavy metal concentrations depending on depth and also for the seasonality of heavy metals upload.
\end{abstract}

Keywords: heavy metals, water quality, water reservoir, seasonality, mathematical models,

\section{INTRODUCTION}

Heavy metal pollution in aquatic environments is a growing problem worldwide and currently it has reached an alarming rate, especially for drinking water sources such as rivers and water reservoirs [1-2].

\footnotetext{
a Technical University of Cluj-Napoca, North University Center at Baia Mare, Faculty of Science, 76 Victoriei Street, 430122, Baia Mare, Romania

b Babeş-Bolyai University, Faculty of Chemistry and Chemical Engineering, 11 Arany Janos str., RO-400028, Cluj-Napoca, Romania

*Corresponding author: firutagoga@yahoo.com
} 
There are various sources of heavy metals in aquatic environment such as natural sources through geological weathering of the rocks and anthropic sources such as mining effluents, industrial effluents, domestic effluents, agricultural nonpoint source pollution, transport or recreational activities (boating, fishing, camping). Heavy metals occur in small amounts naturally and may enter into the aquatic system through leaching of rocks especially by rainwater, atmospheric deposition of airborne dust or industrial emissions, forest fires and vegetation [1, 3-5].

In a water reservoir, heavy metals can be distributed in the water column or can be adsorbed on the surface of suspended particles that are finally deposited as sediments on the bottom. These processes lead to the accumulation of higher levels of heavy metals in sediments [4-5]. However, the dissolved species of heavy metals continuously undergo a chemical exchange with the suspended fraction and bottom sediments [6-7]. The sediments can be a source of heavy metals through resuspension, especially when events such as storms or heavy rainfall occur [8]. Studies showed that aquatic sediments absorb water contaminants to levels significantly higher than the water column concentrations and so they act as endogenic sources of contaminations [9-11].

Heavy metals in aquatic environments can be harmful both to the environment (aquatic organisms including fish) and to human beings [12-13]. Some heavy metals such as $\mathrm{Pb}$ and $\mathrm{Cd}$ are toxic to living organisms, but others are naturally found in the human body at low concentrations and are essential for human health, such as $\mathrm{Fe}, \mathrm{Zn}, \mathrm{Cu}$. $\mathrm{Fe}$, for example, prevents anaemia, and $\mathrm{Zn}$ is a cofactor in over 100 enzyme reactions [7]. In the aquatic environment, metals undergo chemical and biogeochemical processes that control their solubility, mobility, bioavailability and toxicity [14]. It is important to know the distribution of contaminants in lake water because it provides information about their origin, transformation and migration that are useful in water reservoir management $[9,15-16]$.

Water reservoirs provide important services to human communities such as supplying raw water, controlling floods and generating electricity [2]. However, with time, water quality tends to decrease due to sediment accumulation, low flow, accumulation of pollutants in sediments and their release in the water column by diffusive processes or by sediment disturbances [2, 15].

In temperate regions, water quality in a reservoir is not constant across the seasons, but is influenced by rainfall and solar heating, resulting in seasonal variations in water quality and also by the input and output of water [16]. The water content in heavy metals depends on the water depth. In warm seasons, water is stratified due to the incomplete or lower recirculation between the superficial layer of water, the epilimnion, and the deeper layer 
hypolimnion [17]. Thus, the deeper layer is excluded from gas exchange with the atmosphere, leading to anoxic conditions at the bottom of the reservoir. In these anaerobic conditions, reduced chemical species, especially $\mathrm{Fe}$ and $\mathrm{Mn}$ are released from the sediments and enter the hypolimnion [2,17].

The Strîmtori-Firiza Reservoir is the main water supply for Baia Mare town [18-21] being also used for electricity generation, recreational activities, and flood prevention. The reservoir was built between 1961-1964 on the Firiza River and was inaugurated in 1964. It is located at about $10 \mathrm{~km}$ north of Baia Mare municipality and has a total capacity of 16.3 million cubic meters of water with an usable capacity of 13.9 million cubic meters and a maxim depth of $51.5 \mathrm{~m}$ [19]. The Firiza Lake is located upstream of the pollution sources, at a higher altitude than the town [21]. The reservoir is surrounded by forested hills with limited human activity. A road passes on the right bank of the reservoir.

The present study aimed to assess the spatial, seasonal variation and also the influence of depth on the degree of heavy metal upload (Fe, $\mathrm{Mn}$, $\mathrm{Zn}, \mathrm{Cu}, \mathrm{Cd}$ and $\mathrm{Pb}$ ) of the water columns in the Firiza-Strimtori Reservoir. In this purpose, water samples were taken in 10 points of the median part of Firiza-Strîmtori Reservoir at the surface, and at the depth of 5, 10, 15 and $20 \mathrm{~m}$ under the water surface. In addition, the concentrations of the major metals ( $\mathrm{Na}, \mathrm{K}, \mathrm{Ca}$ and $\mathrm{Mg}$ ) in water were analysed to examine possible correlations between data. The originality of the study consists in the complex study that processes a large data base about major and trace metal content in the water column, the variation of metal content with depth, the way in which the seasonality influences the profile of heavy metal concentration with depth.

The results were processed to assess the influences of depth and seasons on the metals content of the water in Firiza-Strîmtori Reservoir. The functions that quantify the dependence of heavy metal content on depth were studied aiming to find the best mathematical models.

Until now there are no studies about the influence of the water column depth on heavy metal content of water in this area.

\section{RESULTS AND DISCUSSION}

\section{Anual variation of metals}

The spatial and temporal variations of the concentration of the major metallic ions and also of the heavy metals in the water samples of Firiza-Strîmtori Reservoir were assessed using 10 sampling points along the median part of the reservoir. 4 sets of samples were taken in the four seasons for 5 depths: $0 \mathrm{~m}$ (at the surface of the water), 5, 10, 15 and $20 \mathrm{~m}$. The average values 
and standard deviations of concentrations of the major cations of metals in Firiza-Strîmtori Reservoir such as $\mathrm{Na}, \mathrm{K}, \mathrm{Ca}$ and $\mathrm{Mg}$ as well as the heavy metals concentration ( $\mathrm{Fe}, \mathrm{Mn}, \mathrm{Zn}, \mathrm{Cu}, \mathrm{Cd}$ and $\mathrm{Pb}$ ) are shown in Table 1.

We see an increase in metal concentrations with depth for each of the analysed metal. As a general trend, the metal concentrations increase with the depth of sampling. The highest absolute increase in concentration values for the maximum depth of $20 \mathrm{~m}$ was found for $\mathrm{Ca}$ with $0.94 \mathrm{mg} / \mathrm{L}$ considering the difference between the average $\mathrm{Ca}$ concentration at surface and the average $\mathrm{Ca}$ concentration at $20 \mathrm{~m}$, followed by $\mathrm{Na}, \mathrm{Mg}, \mathrm{Fe}, \mathrm{Mn}, \mathrm{Zn}$, $\mathrm{Cu}, \mathrm{Pb}$ and $\mathrm{Cd}$.

Table 1. The yearly average values of the metal concentrations in the water samples of Firiza-Strîmtori Lake, mg/L (for 10 sampling points and 4 times of sampling)

\begin{tabular}{|c|l|l|l|l|l|l|}
\hline $\begin{array}{c}\text { Depth } \\
\text { Metals }\end{array}$ & $\mathbf{T V}^{*}$ & \multicolumn{1}{|c|}{$\mathbf{0} \mathbf{~ m}$} & \multicolumn{1}{|c|}{$\mathbf{5} \mathbf{~ m}$} & \multicolumn{1}{|c|}{$\mathbf{1 0} \mathbf{~ m}$} & \multicolumn{1}{|c|}{$\mathbf{1 5} \mathbf{~ m}$} & \multicolumn{1}{c|}{$\mathbf{2 0} \mathbf{~ m}$} \\
\hline $\mathbf{N a}$ & - & $1.42 \pm 0.01$ & $1.48 \pm 0.01$ & $1.55 \pm 0.02$ & $1.61 \pm 0.02$ & $1.68 \pm 0.03$ \\
\hline $\mathbf{K}$ & - & $1.01 \pm 0.02$ & $1.06 \pm 0.02$ & $1.11 \pm 0.02$ & $1.15 \pm 0.015$ & $1.20 \pm 0.013$ \\
\hline $\mathbf{C a}$ & 100 & $5.37 \pm 0.06$ & $5.62 \pm 0.06$ & $5.85 \pm 0.10$ & $6.09 \pm 0.09$ & $6.31 \pm 0.06$ \\
\hline $\mathbf{M g}$ & 50 & $1.46 \pm 0.008$ & $1.52 \pm 0.01$ & $1.58 \pm 0.02$ & $1.64 \pm 0.02$ & $1.71 \pm 0.021$ \\
\hline $\mathbf{F e}$ & 0.2 & $0.249 \pm 0.001$ & $0.285 \pm 0.004$ & $0.320 \pm 0.005$ & $0.359 \pm 0.005$ & $0.399 \pm 0.003$ \\
\hline $\mathbf{M n}$ & 0.05 & $0.082 \pm 0.0014$ & $0.106 \pm 0.003$ & $0.131 \pm 0.002$ & $0.162 \pm 0.003$ & $0.191 \pm 0.004$ \\
\hline $\mathbf{Z n}$ & 5 & $0.018 \pm 0.002$ & $0.038 \pm 0.002$ & $0.064 \pm 0.003$ & $0.085 \pm 0.004$ & $0.107 \pm 0.003$ \\
\hline $\mathbf{C u}$ & 0.1 & $(19 \pm 0.76) \cdot 10^{-4}$ & $(20 \pm 0.62) \cdot 10^{-4}$ & $\left(22 \pm 0.73 \cdot 10^{-4}\right.$ & $(24 \pm 0.66) \cdot 10^{-4}$ & $\left(26 \pm 0.62 \cdot 10^{-4}\right.$ \\
\hline $\mathbf{C d}$ & 0.005 & $(32 \pm 1.7) \cdot 10^{-6}$ & $(55 \pm 2) \cdot 10^{-6}$ & $(77 \pm 3) \cdot 10^{-6}$ & $(99 \pm 4) \cdot 10^{-6}$ & $(122 \pm 4) \cdot 10^{-6}$ \\
\hline $\mathbf{P b}$ & 0.01 & $(14 \pm 0.51) 10^{-4}$ & $(15 \pm 0.57) \cdot 10^{-4}$ & $(17 \pm 0.71) \cdot 10^{-4}$ & $(19 \pm 0.91) \cdot 10^{-4}$ & $(21 \pm 0.12) \cdot 10^{-4}$ \\
\hline
\end{tabular}

*Threshold value for drinking water according to Romanian legislation

Considering the ratio between the metal average concentration at surface $(0 \mathrm{~m})$ and at $20 \mathrm{~m}$ depth, the highest value was found for $\mathrm{Zn}$ (about 6 ) followed by $\mathrm{Cd}$ (3.9), $\mathrm{Mn}$ ( 2.3), $\mathrm{Fe}$ (1.6), $\mathrm{Pb}$ and $\mathrm{Cu}$ around 1.4 while for $\mathrm{Mg}, \mathrm{Ca} \mathrm{Na}$ and $\mathrm{K}$, the ratio was very close around 1.18 . The levels of distribution for the studied metals are presented in Fig. 1.

Heavy metal concentrations do not exceed the contamination threshold value for drinking water except for Fe and Mn. The water of Firiza-Strimtori Reservoir has a good quality and can be used as raw material for preparing drinking water in the treatment plant where it is subjected to treament processes, finally obtaining values under the maximum concentration allowed for all metals. 


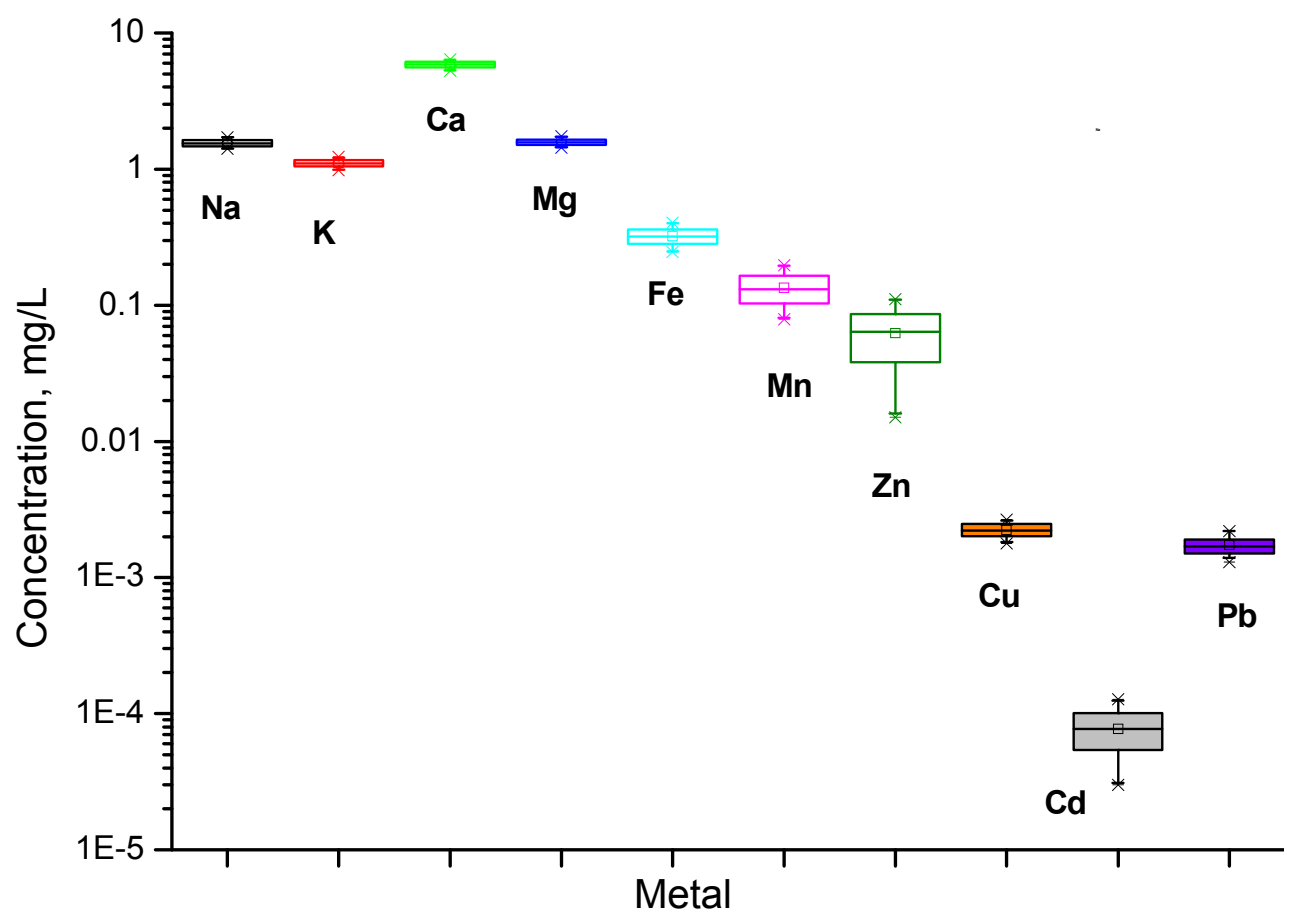

Figure 1. The distribution of the concentration of major metals and heavy metals in the Strîmtori-Firiza Reservoir for the 10 sampling points and 5 levels of depth

By correlating the average values of metals concentration presented in Table 1 and the levels of concentrations depicted in Figure 1 as Box plot it can be concluded that the concentration of the studied metals decreases in the following sequence: $\mathrm{Ca}>\mathrm{Na}>\mathrm{Mg}>\mathrm{K}>\mathrm{Fe}>\mathrm{Mn}>\mathrm{Zn}>\mathrm{Cu}>\mathrm{Pb}>\mathrm{Cd}$. For all the studied metals, an increasing with depth was observed, probably due to the release of the metal ions into the water column as an endogenic source of contamination based on the alteration in the oxidation-reduction status of sediments. In Firiza-Strîmtori Reservoir, the heavy metal sources were the weathering of volcanic rocks that are found in the area and also the industrial atmospheric deposition over the reservoir during decades when a copper smelter and a lead smelter have worked in Baia Mare. Since 2008 and 2010 respectively, these smelters have been closed, but the atmospheric powders deposed as sediments to the bottom of the reservoir can be released from the sediments being an endogenic source of pollution. 
The last years have shown a trend of enhancement in pollution by heavy metals present in the sediments of surface water $[8,14]$. In this context, the distribution pattern of contaminants across the water column could provide some useful information on the environmetal characteristics of heavy metals such as their transformation and migration [9].

\section{Seasonal variation of metals}

Figures 2 and 3 show the variation of the concentrations of metals with depth across the four seasons for each of the 10 sampling points. Thus, a family of curves was obtain showing the degree of reproducibility and of homogeneity of the water within the reservoir for each analysed metal. Also, the differences between the 4 seasons regarding the metal concentration in water columns could be observed. The variation of the metal concentrations with depth indicated an increase of the concentration with said depth [22-24].

$\mathrm{Na}$ concentrations in the reservoir water decreased in autumn and winter compared to those registered in spring and summer. This trend could be explain by the dilution effect in the cold seasons, richer in precipitation. A similar pattern was found in the case of $\mathrm{K}$, with the exception of a partial overlap of the functions that described potassium concentrations depending on depth, $\mathrm{C}_{\mathrm{K}}=\mathrm{f}$ ( depth).

$\mathrm{Ca}$ content in water was highest in winter, decreased in summer, decreasing even more in spring. The lowest concentrations of $\mathrm{Ca}$ were registred in autumn. Mg shows similar trend with a certain particularity: the lowest values were found in spring. $\mathrm{Ca}$ and $\mathrm{Mg}$ concentrations in water are influenced by the carbon dioxide content of water that increases in the cold seasons due to a higher solubility. Also, in the warm seasons, due to the photosynthesis process as well as to the decomposition of the organic matter, the water content in carbon dioxide was enriched.

Fe concentration trends were similar to those of $\mathrm{Mn}$ in Firiza-Strîmtori Reservoir: the highest values were registered in spring, followed by those found in winter. The lowest values of $\mathrm{Fe}$ and $\mathrm{Mn}$ concentrations were found in autumn and summer. In the warm season a stratification of the reservoir occurs and thus anoxic conditions are found. Part of the heavy metals precipitate in the reductive medium as metal sulphides [22-23].

The concentrations of heavy metals are shown in Fig. 3 . In the case of $\mathrm{Zn}$ there is not a clear difference between the pattern of $\mathrm{Zn}$ depending on the depth for the four set of data sampled in different seasons. However, a downward trend of the concentrations found in warm seasons (summer and spring) compared to the colder ones (winter and autumn) can be observed. 

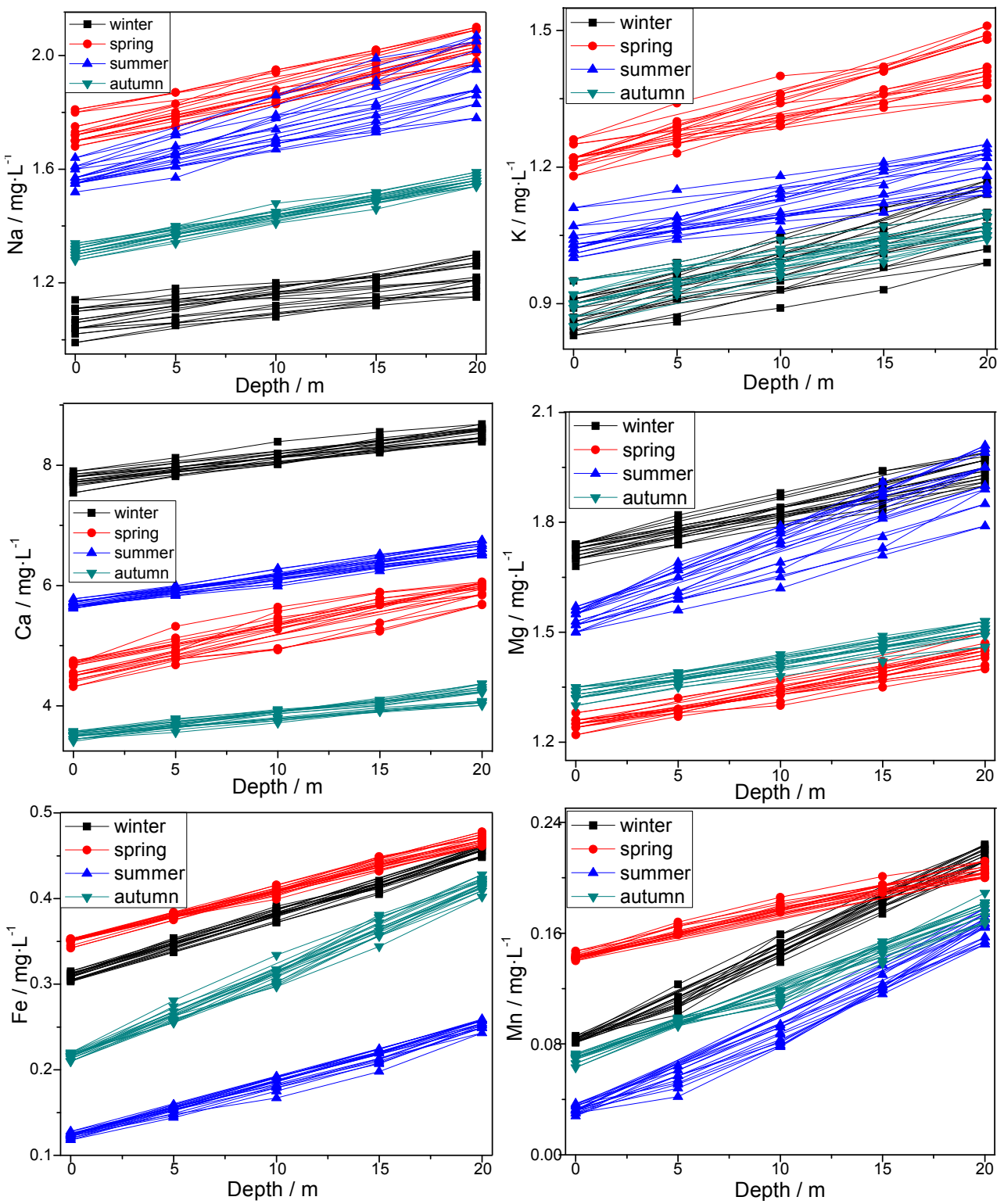

Figure 2. The variation of $\mathrm{Na}, \mathrm{K}, \mathrm{Ca}, \mathrm{Mg}, \mathrm{Fe}$ and $\mathrm{Mn}$ depending on season and depth 
Higher concentrations were found for $\mathrm{Zn}$ in the summer especially at the depth of 10,15 and $20 \mathrm{~m}$, showing a stratification of the reservoir water that is specific to the warm season.

In the case of $\mathrm{Cu}$, the highest concentrations were registered in winter followed by those found in summer and autumn. The lowest concentrations were found in spring, probably due to the dilution effect of precipitations and runoff in the reservoir.

Cd showed the highest concentrations in summer and spring. A lowering trend was observed in winter and autumn.
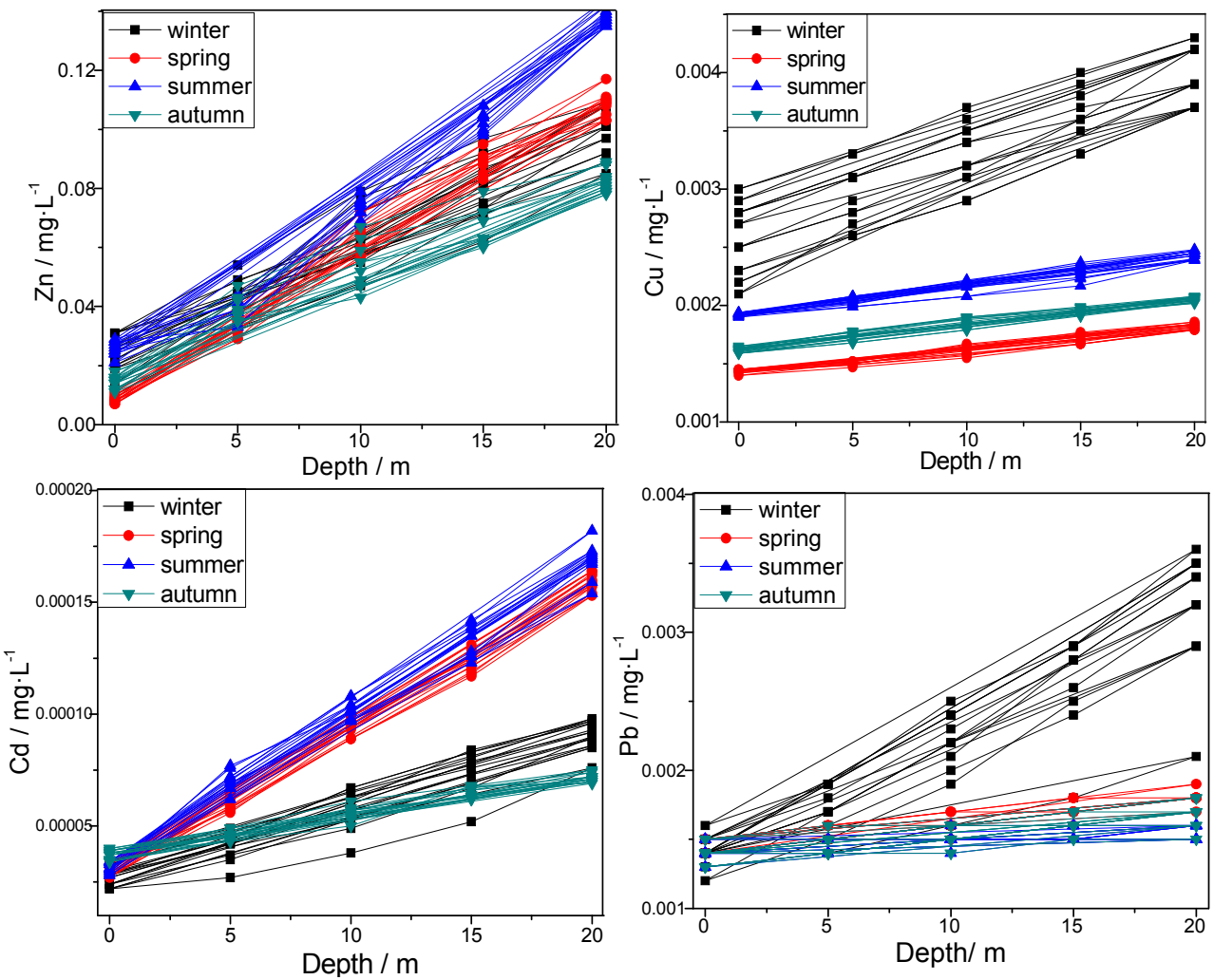

Figure 3. The variation of $\mathrm{Zn}, \mathrm{Cu}, \mathrm{Cd}$, si $\mathrm{Pb}$ depending on season and depth in the 10 sampling points of the Strîmtori-Firiza Reservoir

The $\mathrm{Pb}$ concentrations showed a low variability and they were higher in winter. 

with depth.

The concentrations of $\mathrm{Zn}$ as the other analyzed heavy metals increased

The differences between the concentrations of $\mathrm{Fe}, \mathrm{Mn}, \mathrm{Cu}, \mathrm{Cd}$ and $\mathrm{Pb}$ at water surface and those found in the deeper layers are caused by the differences in $\mathrm{pH}$ and redox conditions [23].

In figure 4, the distribution of levels of heavy metals for the four seasons is shown. The highest concetrations of $\mathrm{Ca}$ were registred in winter. The seasonal variation of $\mathrm{Pb}, \mathrm{Cd}, \mathrm{Cu}, \mathrm{Mn}$ and $\mathrm{Zn}$ concentrations could be explained by the different trends of the suspended particulate matter in different seasons. The suspeded particulate matter is the main agent that promotes the vertical transport of the heavy metals. In the warm seasons, summer and spring, the stratification of water column occurs while in winter and autumn the vertical mixing of the water layers prevails [23].
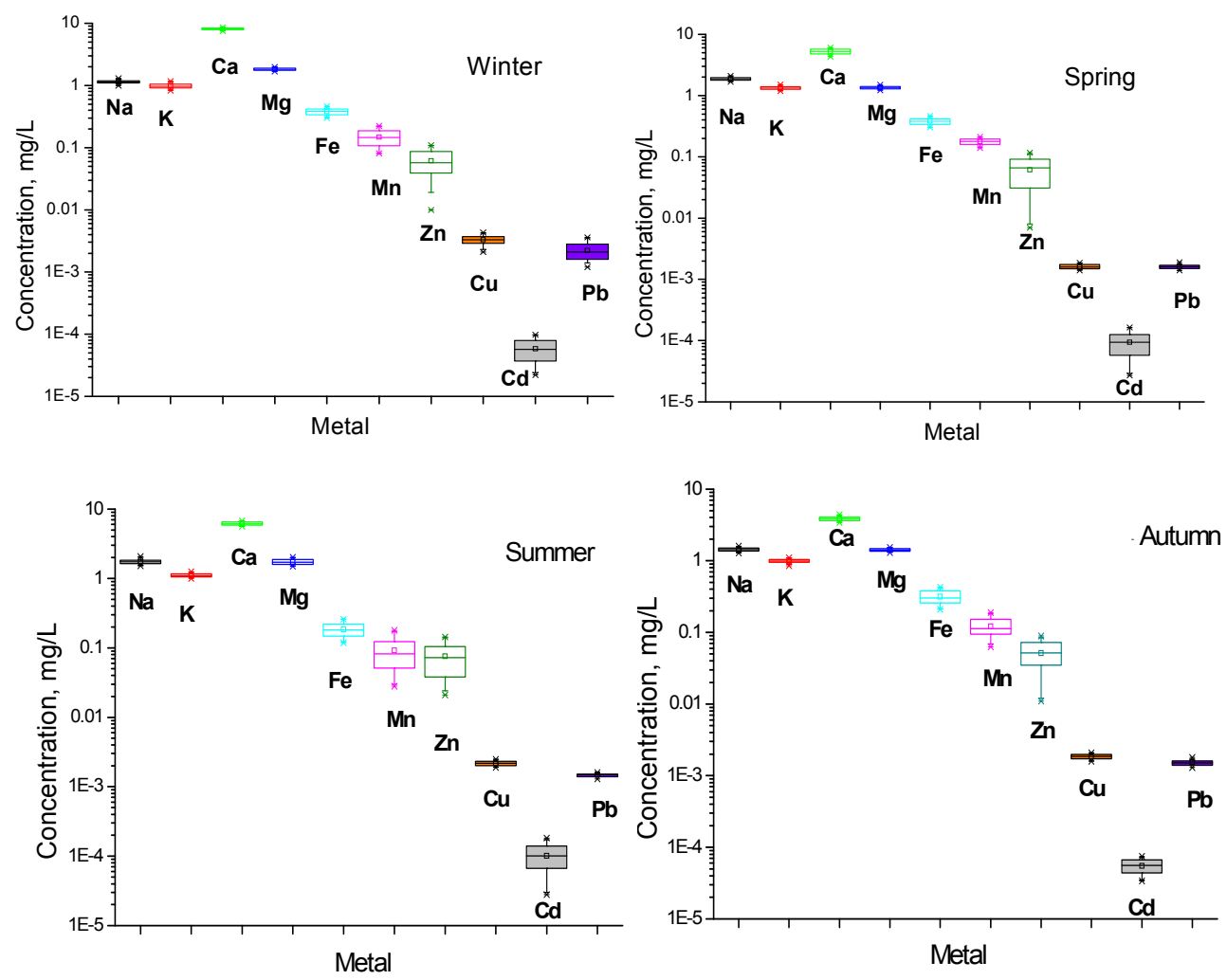

Figure 4. The levels of concentration of the major metals and heavy metals depending on the seasons 


\section{Comparative study of iron concentration in raw and filtrated water}

In Fig. 5 the variations of the Fe concentrations with the depth in the four seasons for the filtered water and for the raw (unflitred) water that contains the Fe ions in the dissolved forms and also the colloidal forms of Fe are plotted. The highest values of $\mathrm{Fe}$ contents in the raw (unfiltered) water samples were found in winter while in the filtered water, the highest concentrations were found in summer and the lowest ones were found in spring, both for the unfiltered and for filtered water as it is shown in Fig. 5.

The study was performed only for Fe content. Among heavy metals, Fe was present in the highest concentrations and the trendency of Fe to pass in coloidal forms due to the hidrolysis and oxidation processes is well known.

The presence of iron in higher concentration in raw and filtered water is explained by the colloidal iron [20]. Most metallic elements such as $\mathrm{Pb}, \mathrm{Cd}$, $\mathrm{Cu}$ and $\mathrm{Zn}$ are toxic for aquatic biota [20].
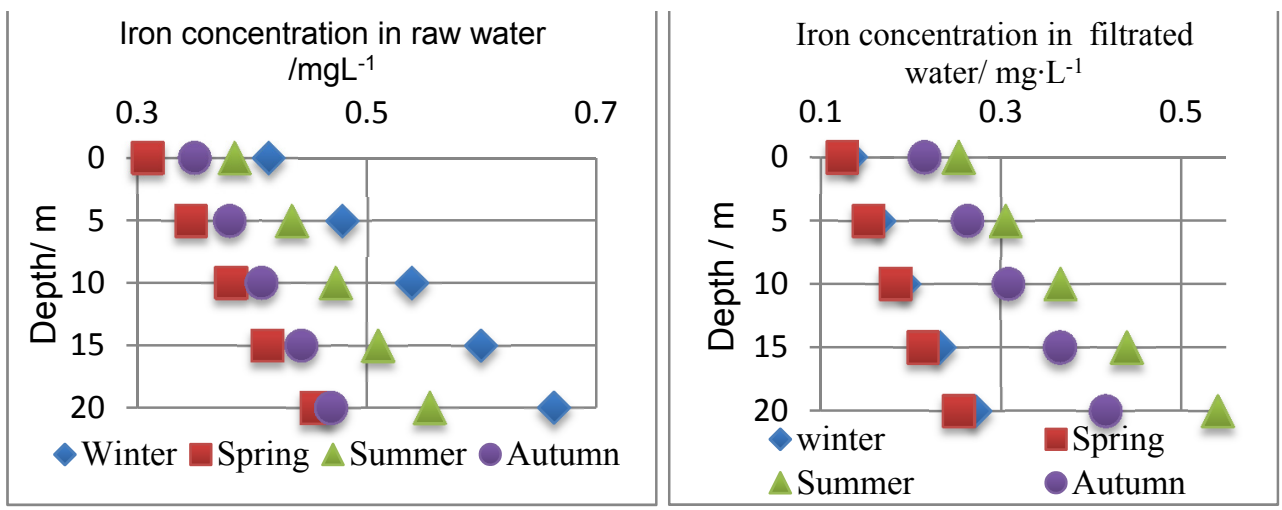

Figure 5. The comparison between the concentrations of iron $(\mathrm{Fe})$ in the raw water (left) and in the filtered water (right)

\section{Mathematical modeling}

The mathematical model aimed to find the dependence of the studied heavy metal concentrations with depth. Nonlinear regression method was applied in order to obtain the function with the best-fitted values of the metal concentrations. Based on the mathematical models that fit the experimental data the study attempted to predict the future trends of the analyzed metal concentrations in reservoir water.

The mathematical models that better described the variation of the metals' concentrations with depth and the seasonality as a function of metals' concentration in different seasons consist of a set of non-linear functions obtained by regression with Table Curve Windows program. 
Some of the heavy metals' concentrations are strongly correlated. The highest correlations were found for $\mathrm{Mn}$ and $\mathrm{Fe}, \mathrm{Zn}$ and $\mathrm{Cd}$ and also for the major elements $\mathrm{Mg}$ and $\mathrm{Ca}$.

The variation of heavy metal content with depth was subjected to mathematical analysis of data trying to find the function describing the increase of metals with depth. Only in the case of $\mathrm{Zn}$ a function with a good correlation coefficient was found.

The mathematical model that describes the variation of $\mathrm{Zn}$ concentration with depth is a polynomial function given by the equation (1) with the model accuracy indicator, $R^{2}=0.858(F=294)$

$$
y=0.018-0.0056 x+0.0086 x^{1.5}-0.0024 x^{2}+0.000214 x^{2.5}
$$

The accordance between the results generated by the mathematical models and the experimental data showed that a multivariable model can be utilized in the estimation of the correlations among the different metals' concentration is presented in table 2 . In this purpose a model was utilized based on a function $f(x, y, z)$ generated by the TableCurve3D program. The shapes of the function are shown in Fig. 6.

Table 2. Mathematical models obtained by correlation of different heavy metals concentration

\begin{tabular}{|c|c|c|c|}
\hline \multirow[t]{2}{*}{ Variation } & \multirow{2}{*}{ Matematical model } & \multicolumn{2}{|c|}{$\begin{array}{l}\text { Model accuracy } \\
\text { indicator }\end{array}$} \\
\hline & & $\mathbf{R}^{2}$ & $\mathbf{F}$ \\
\hline $\mathrm{Mn}=\mathrm{f}(\mathrm{Fe})$ & $\begin{array}{c}y=0.9-68 x+2111 x^{2}-32409 x^{3}+282469 x^{4}- \\
1422373 x^{5}+3862949 x^{6}-4378076 x^{7}\end{array}$ & 0.810 & 116 \\
\hline $\mathrm{Cd}=\mathrm{f}(\mathrm{Zn})$ & $\begin{aligned} y= & 0.000006-0.0061 x+0.47 x^{2}-18.78 x^{3}+419 x^{4}- \\
& 5654 x^{5}+44909 x^{6}+191037 x^{7}+333034 x^{8}\end{aligned}$ & 0.821 & 110 \\
\hline $\mathrm{Mg}=\mathrm{f}(\mathrm{Ca})$ & $\begin{array}{c}y=41011-74696 x+60518 x^{2}-28726 x^{3}+8848 x^{4}- \\
1848 x^{5}+265 x^{6}-25 x^{7}\end{array}$ & 0.902 & 174 \\
\hline $\mathrm{Pb}=\mathrm{f}(\mathrm{Ca}, \mathrm{Mg})$ & $z=-0.18-0.24 x \ln x+0.16 x^{2}-0.05 x^{3} \ln x+0.002 x^{3}$ & 0.802 & 151 \\
\hline $\mathrm{Cd}=\mathrm{f}(\mathrm{Mn}, \mathrm{Fe})$ & $z=-0.0019-0.0011 x+0.28 y-0.013 y^{2}+0.015 y^{3}$ & 0.772 & 167 \\
\hline $\mathrm{Cd}=\mathrm{f}(\mathrm{Zn}, \mathrm{Cu})$ & $\begin{array}{c}z=0.000033+0.0027 x-0.67 x^{2}+0.67 x^{3}-2.38 y^{2}- \\
0.016 y-0.072 y^{2}\end{array}$ & 0.881 & 237 \\
\hline$P b=f(C u, C d)$ & $\begin{array}{c}z=0.0021+0.031 x+0.89 y-1.88 x^{2}-2.24 y^{2}- \\
0.088 x y\end{array}$ & 0.810 & 157 \\
\hline
\end{tabular}

Both metals, $\mathrm{Mn}$ and $\mathrm{Fe}$, are found in more oxidation states, they vary with the depth in a similar manner and are susceptible to oxidation or reduction. At higher depths due to the lack of oxygen, these metals are found in the reduced oxidation states [2,25]. Cd and $\mathrm{Zn}$ are known to be geochemically similar and similar also in their behavior in the environment [25]. 

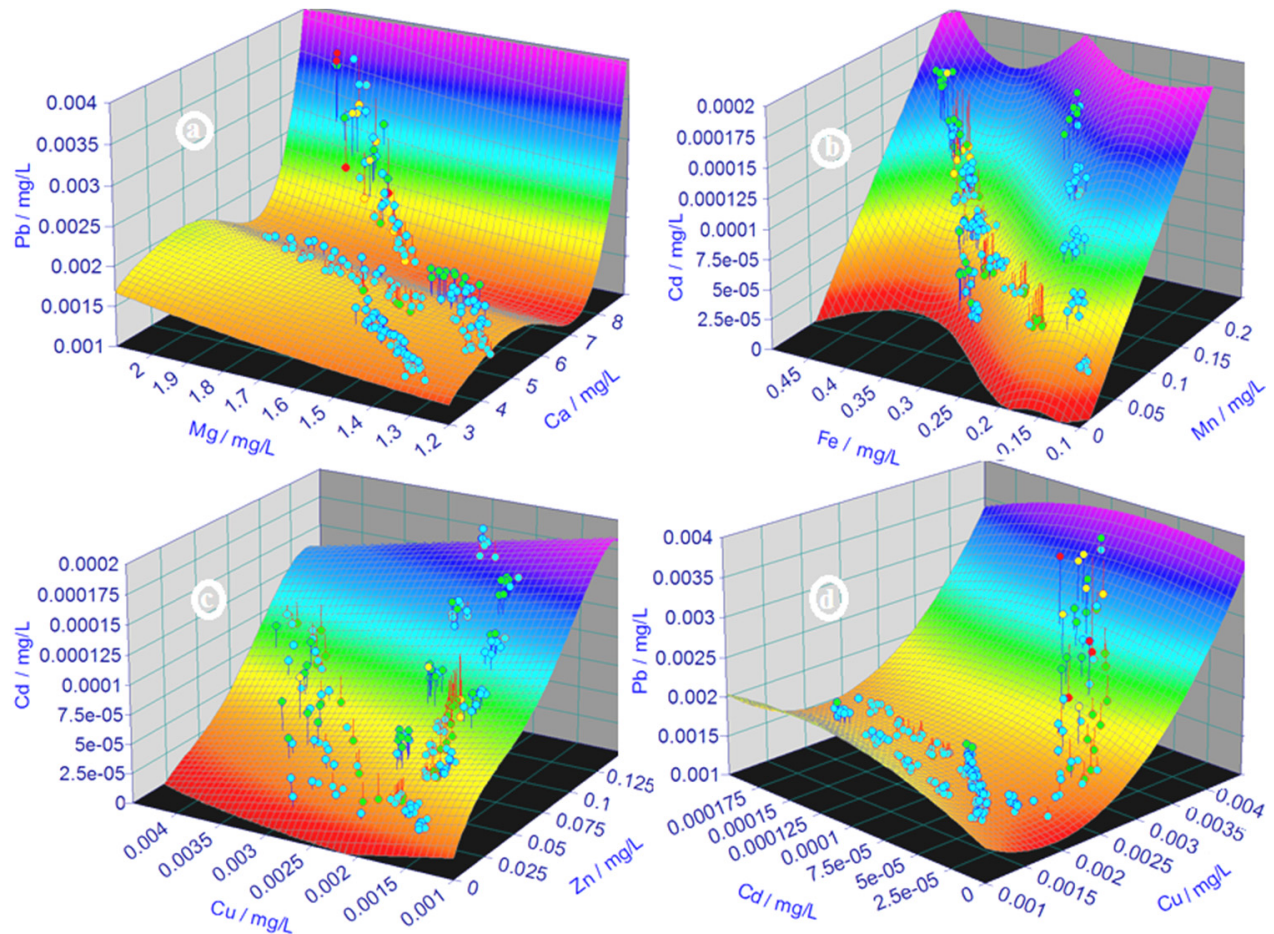

Figure 6. Mathematical models for the correlation of following group of metals: $(\mathrm{CMg}, \mathrm{CPb})=\mathrm{f}\left(\mathrm{C}_{\mathrm{Ca}}\right) ;\left(\mathrm{CFe}_{\mathrm{Fe}}, \mathrm{CCd}\right)=\mathrm{f}(\mathrm{CMn}) ;(\mathrm{CCu}, \mathrm{CCd})=\mathrm{f}(\mathrm{CZn}) ;(\mathrm{CCd}, \mathrm{CPb})=\mathrm{f}(\mathrm{CCu})$

Also, the mathematical models of the metal concentrations depending on the season were established. Thus, in the case of metal concentration in water of Firiza-Strîmtori reservoir function of seasonality a 3D mathematical model, described in table 3 and figure 7 , was obtained.

Table 3. Mathematical models obtained by correlation of the heavy metals concentration in different seasons

\begin{tabular}{|c|c|c|c|}
\hline \multirow{2}{*}{ Variation } & \multirow{2}{*}{ Matematical model } & \multicolumn{2}{|c|}{$\begin{array}{l}\text { Model accuracy } \\
\text { indicator }\end{array}$} \\
\hline & & $\mathbf{R}^{2}$ & $\mathbf{F}$ \\
\hline $\mathrm{Cu}_{\text {summer }}=\mathrm{f}\left(\mathrm{Cu}_{\text {spring }}, \mathrm{C}\right.$ Uautumn $)$ & $\begin{array}{c}z=57-28 \ln x+3(\ln x)^{2}-0.36(\ln x)^{3}- \\
0.09(\ln x)^{4}-0.005(\ln x)^{5}+0.01 y^{-1}\end{array}$ & 0.962 & 94 \\
\hline$Z n_{\text {spring }}=\mathrm{f}\left(Z \mathrm{n}_{\text {summer }}, Z n_{\text {winter }}\right)$ & $\begin{array}{l}z=0.034-1.09 x+41 x^{2}-485 x^{3}- \\
2028 x^{4}-0.124 y+12.3 y^{2}-37.3 y^{3}\end{array}$ & 0.981 & 333 \\
\hline $\mathrm{Cd}_{\text {summer }}=\mathrm{f}\left(\mathrm{Cd}_{\text {autumn }}, \mathrm{C} \mathrm{d}_{\text {spring }}\right)$ & $\begin{aligned} z= & 0.001+191.5 x^{2}+208.5 y^{2} \ln y \\
& +0.043 y^{0.5}+0.0128(\ln y)^{-1}\end{aligned}$ & 0.971 & 343 \\
\hline$F e_{\text {spring }}=f\left(F e_{\text {summer }}, F e_{\text {winter }}\right)$ & $\ln z=-1.27+3.15 x^{2,5}-0.12 y^{-2}$ & 0.980 & 1181 \\
\hline
\end{tabular}



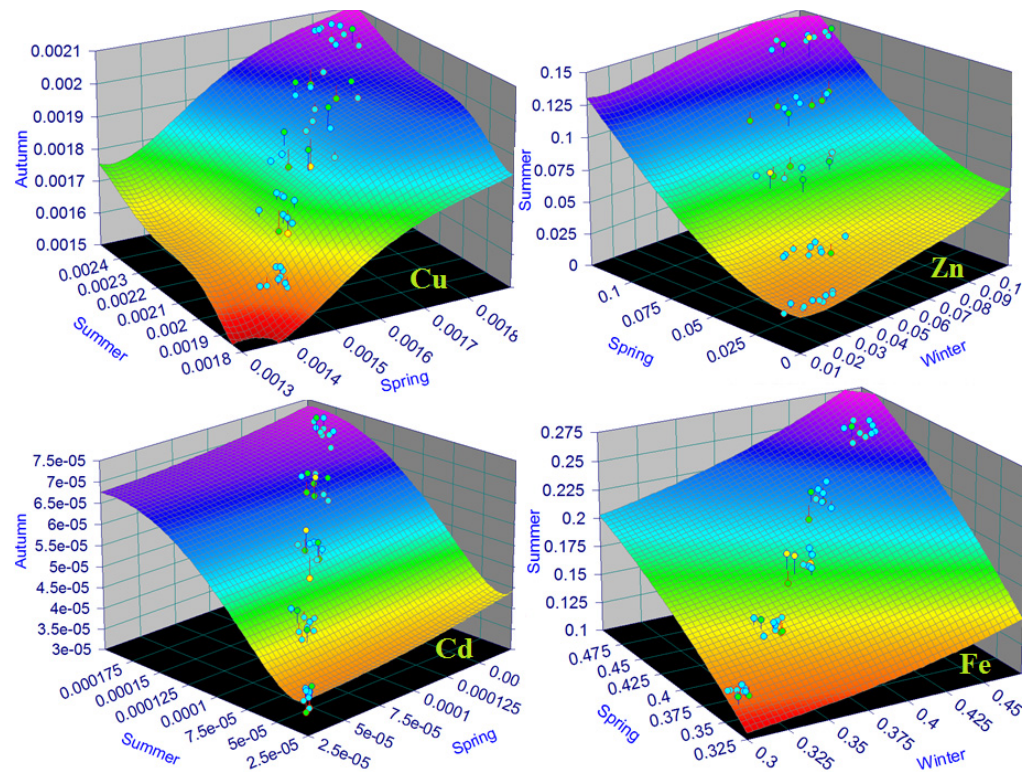

Figure 7. Mathematical models of correlation between the concentrations of $\mathrm{Cu}, \mathrm{Zn}$, $\mathrm{Cd}$ and Fe across the seasons

There concentrations of the heavy metals in different seasons showed good correlations with correlation coefficients higher than 0.96 showing a relative constancy of water composition across the seasons. The function shows a similar seasonality as in the case of Cu probably due to similar sources of these heavy metals: endogen sources, the resuspension of sediments and exogen ones as fertilizers and pesticides) [25]. For all the developed models, the increase of the upload of metals with depth due to the accumulation trend of heavy metals to the bottom of Firiza-Strîmtori Reservoir is obvious.

\section{EXPERIMENTAL SECTION}

\section{Sampling}

Water samples were collected from 10 sampling points along the lake Strîmtori-Firiza (Fig. 8) in four sampling campaigns during the year 2015: February $10^{\text {th }}$, April $20^{\text {th }}$, August $10^{\text {th }}$ and October $14^{\text {th }}$ in order to obtain specific data for the seasonality. In each sampling point, the water samples were collected form 5 depth: $0,5,10,15$ and $20 \mathrm{~m}$. With this purpose, the water samples were taken using a boat equipped with a telescopic sampler of $20 \mathrm{~m}$ length. The collected samples were prepared in order to the determination the heavy metal content. In this respect, a mineralization of water samples with aqua regia $\left(\mathrm{HNO}_{3} 67 \%: \mathrm{HCl} 37 \%=3: 1\right)$ was realized. 


\section{Analysis of metals}

The $\mathrm{Na}, \mathrm{K}, \mathrm{Ca}$ and $\mathrm{Mg}$ were analysed by atomic emission spectrometry while the heavy metals analysis ( $\mathrm{Fe}, \mathrm{Mn}, \mathrm{Zn}, \mathrm{Cu}, \mathrm{Pb}, \mathrm{Cr}$, Cd) according to SR ISO8467/2001, was done by flame absorption atomic spectrometry and by graphite furnace atomic absorption spectrometry using a Perkin Elmer spectrophotometer. Flame Atomic Absorption Spectrometry and Flame Atomic Emission Spectrometry are techniques recommended for detecting metals in environmental samples [25-26]. For the heavy metals present in samples at low levels such as $\mathrm{Cd}, \mathrm{Cu}$ and $\mathrm{Pb}$, Graphite Furnace Atomic Absorption Spectrometry was used. This technique is a more efficient atomizer than a flame and it can directly accept very small absolute quantities of sample. Samples are placed directly into the graphite furnace, then, they are heated in several steps to dry the sample, ash organic matter, and vaporize the analyte atoms.

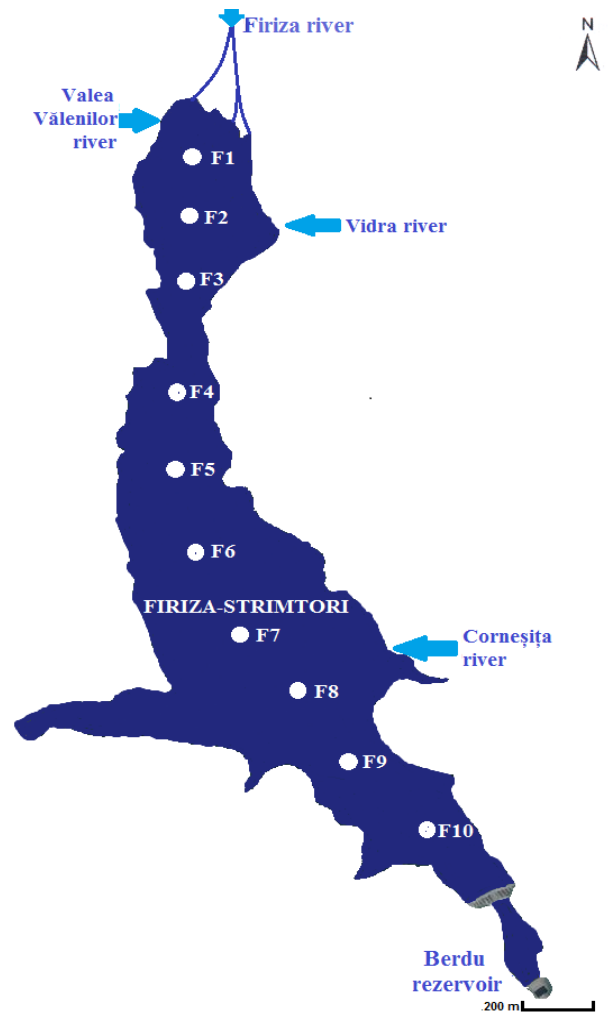

Figure 8. The map of Strîmtori-Firiza Reservoir showing the 10 sampling points (located along its median part)

\section{Models development}

The four sets of data sampled in the four seasons, each at them containing 10 sampling points with 5 depth were statistically analysed and shown using Box plot graphics. Models of correlations between the metal concentrations and depth were developed using regression analysis with TableCurve Windows program. We chose the models with the best-fit values of variables quantified by model accuracy indicator, $R$. The analysed variables were metals' concentrations and depth. The 3D correlations were established between the metal concentrations. The influence of seasons on heavy metal upload was established by developing 3D models with the best model accuracy. 


\section{CONCLUSIONS}

A complex study on the spatial and seasonal variability of major metals $(\mathrm{Na}, \mathrm{K}, \mathrm{Ca}, \mathrm{Mg}$ ) and also of heavy metals (Fe, Mn, $\mathrm{Cu}, \mathrm{Zn}, \mathrm{Cd}$ and $\mathrm{Pb}$ ) was accomplished for the water of Firiza-Strîmtori Reservoir that is the main source of drinking water for the municipality of Baia Mare. The influence of depth on the concentration of metals was studied and models of the concentration's variation with depth were developed. An increase of metals' concentrations with depth for all metals but in different extent was found. In spring the highest values were found for $\mathrm{Na}, \mathrm{K}, \mathrm{Fe}$ and $\mathrm{Mn}$, while in winter higher values for $\mathrm{Ca}$, $\mathrm{Mg}, \mathrm{Cu}$ and $\mathrm{Pb}$ were found. The lowest concentrations of $\mathrm{Na}$ and $\mathrm{K}$ were found in winter while in summer the lowest uploads of $\mathrm{Fe}$ and $\mathrm{Mn}$ were determined. $\mathrm{Mg}$ and $\mathrm{Cu}$ concentrations were lowest in spring while in autumn lowest concentrations for $\mathrm{Ca}, \mathrm{Zn}, \mathrm{Cd}$ and $\mathrm{Pb}$ were found. Models that quantify the influence of depth on metals' concentrations were proposed. The correlation between the groups of metals such as ( $\mathrm{Ca}, \mathrm{Mg}, \mathrm{Pb}),(\mathrm{Mn}, \mathrm{Fe}, \mathrm{Cd}),(\mathrm{Zn}, \mathrm{Cu}$, $\mathrm{Cd}),(\mathrm{Cu}, \mathrm{Cd}, \mathrm{Pb})$ were established as $3 \mathrm{D}$ models. The influence of the season on metals' concentration was studied for $\mathrm{Cu}, \mathrm{Zn}, \mathrm{Cd}$ and Fe.

\section{REFERENCES}

1. D.O. Ogoyi, C.J. Mwita, E.K. Nguu, P.M. Shiundu, The Open Environmental Engineering Journal, 2011, 4, 156-161.

2. T. Hunag, X. Li, H. Rijnaarts, T. Grotenhuis, W. Ma, X. Sun, J. Xu, Science of the Total Environment, 2014, 485-486, 820-827.

3. E. Nixdorf, B. Boehrer, Hydrology and Earth System Sciences, 2015, 19, 45054515.

4. S. Chowdhury, M.A. Jafar Mazumder, O. Al-Attas, T. Husain, Science of the Total Environment, 2016, 569-570, 476-488.

5. H. Bing, J. Zhou, Y. Wu, X. Wang, H. Sun, R. Li, Environmental Pollution, 2016, 485-496.

6. L. Zhang, Q. Liao, S. Shao, N. Zhang, Q. Shen, C. Liu, International Journal of Environmental Research and Public Health, 2015, 12, 14115-14131.

7. I. Nhapi, U.G. Wali, D. Usanzineza, J.J. Kashaigili, N. Banadda, R. Kimwaga, The Open Environmental Engineering Journal, 2012, 5, 96-102.

8. M. Wojtkowska, J. Bogacki, A. Witeska, Science of the Total Environment, 2016, 551-552, 387-392.

9. Y. Wang, Jiwei Hu, K. Xiong, X. Huang, S. Duan, Procedia Environmental Sciences, 2012, 16, $51-58$. 
10. P. Palma, L. Ledo, S. Soares, I.R. Barbosa, P. Alvarenga, P., Science of the Total Environment, 2014, 470-471, 780-790.

11. Q. Gao, Y. Li, Q. Cheng, M. Yu, B. Hu, Z. Wang, Z. Yu, Water Research, 2016, 92, 262-274.

12. C.Y. Chen, R.S. Stemberger, B. Klaue, J.D. Blum, P.C. Pickhardt, C.L. Folt, Limnology and Oceanography, 2000, 45(7), 1525-1536.

13. M.M. Arafa, A.T. Ali, Egyptain Journal of Comparative Pathology and Clinical Path, 2008, 21(3), $191-201$.

14. A. Kuriata-Potasznik, S. Szymczyk, A. Skwierawski, K. Glinska-Lewczuk, I. Cymes, Water, 2014, 358 (8), doi:10.3390/w8080358.

15. G. Wang, A.Yinglan, H. Jiang, Q. Fu, B. Zheng, Journal of Hydrology, 2015, 520, 37-51.

16. A. Serafim, M. Morais, P. Guilherme, P. Sarmento, M. Ruivo, A. Magrico, Limnetica, 2006, 25, 771-786.

17. X. Li, T. Huang, W. Ma, X. Sun, H. Zhang, Science of the Total Environment, 2015, 521-522, 27-36.

18. S. Filip, 'Depresiunea și Munceii Băii Mari - studiu de geomorfologie environmentală`, Presa Universitară Clujeană, Cluj-Napoca, 2008, p. 186.

19. Cical, E., 'Contribuții privind îmbunătățirea tehnologiei de potabilizare a apei provenită din lacurile de acumulare`, Editura Politehnica, Timișoara, 2010, 63-65.

20. E. Cical, C. Mihali, M. Mecea, A. Dumuţa, T. Dippong, Studia UBB Chemia, 2016, LXI(2), 225-238.

21. O-C. Modoi, C. Roba, Z. Török, A. Ozunu, Environmental Engineering and Management Journal, 2014, 13(9), 2325-2336.

22. D. Chapman, 'Water quality assessments: A guide to the use o biota, sediments and water in environmental monitoring', 2nd ed., Chapman \& Hall, London, 1996, 108-168.

23. C. Rădulescu, C. Stihi, I.D. Dulama, E.D. Chelarescu, P. Bretcan, D. Tanislav, Romanian Journal of Physics, 2015, 60(1-2), 246-256.

24. C. Rădulescu, I.D. Dulama, C. Stihi, I. Ionita, A. Chilian, C. Necula, E.D. Chelarescu, Romanian Journal of Physics, 2014, 59(9-10), 1057-1066.

25. J.A. Plant, N. Voulvoulis, K. Vala, 'Pollutants, Human Health and the Environment: A Risk Based Approach`, Wiley-Blackwell, John\&Sons, Ltd. Publication, Oxford, 2012, 90-98.

26. E. Darvasi, N. Muntean, C. Szentkirályi, Studia UBB Chemia, 2016, LXI(3), 311320. 